\title{
O e-commerce e os fundos imobiliários logísticos: estratégias de captura de rendas imobiliárias
}

\author{
E-commerce and logistics real estate investment trusts: \\ strategies for extracting land rents
}

Maira Magnani [I] Daniel Sanfelici [II]

Resumo

0 volume de recursos direcionados para o mercado imobiliário comercial cresceu rapidamente nos últimos anos com o advento da financeirização. Neste trabalho, examinamos o processo de financeirização do setor logístico brasileiro, argumentando que ele está relacionado com a atuação de fundos de investimento imobiliário. Procuramos mostrar que esses atores financeiros desenvolveram estratégias de extração de rendas imobiliárias se aproveitando de dois processos concomitantes: de um lado, a crescente demanda de empresas varejistas por espaços logísticos - acelerada com a pandemia da Covid-19 -; e, de outro, da procura dos investidores brasileiros por investimentos tidos como "alternativos". Concluímos que esses atores possuem critérios particulares de risco e retorno que resultam em investimentos altamente seletivos, tanto em localização, como em características construtivas e de escolha de locatários.

Palavras-chave: logística; fundo de investimento imobiliário; mercado imobiliário; comércio eletrônico; financeirização.

\begin{abstract}
The amount of resources channeled to the commercial real estate market has grown rapidly in recent years with the rise of financialization. In this paper we analyze the financialization of the Brazilian logistics sector, arguing that it is linked to the operation of real estate investment trusts. We seek to show that these financial players have deployed strategies to extract land rents by taking advantage of two related processes: the retail companies' growing demand for logistic space - accelerated by the Covid-19 pandemic -; and the Brazilian investors' demand for the so-called 'alternative' investments. We conclude that these players have particular risk and return criteria that result in highly selective investments in terms of localization, construction characteristics and selection of tenants.
\end{abstract}

Keywords: logistics; real estate investment trusts; real estate; e-commerce; financialization. 


\section{Introdução}

O crescimento no volume de recursos administrados por investidores institucionais, como fundos de pensão e seguradoras, e por intermediários financeiros, como gestoras de ativos, tem se acelerado ao longo das últimas décadas, em consonância com mudanças nos sistemas de proteção social e, mais amplamente, no padrão de intervenção do Estado na economia (French, Leyshon e Wainwright, 2011; Froud, Johal e Williams, 2002; Clark e Monk, 2017). Essa tendência à concentração da poupança em veículos coletivos de investimento tem induzido os seus gestores a buscarem alternativas em relação aos canais mais tradicionais de investimento em ativos, como títulos da dívida pública, ações e títulos privados (Dixon, 2014). Nessa conjuntura, novos instrumentos financeiros passam a ser criados, utilizando-se da securitização de fluxos de rendimento a partir de ativos reais, incluindo objetos urbanos, como infraestruturas e imobiliário comercial (Lizieri, 2009; Halbert e Attuyer, 2014; Wijburg e Aalbers, 2017). Em que pesem a variabilidade de estratégias e as expectativas que orientam as decisões de investimento desses atores que procuram no urbano um modo de rentabilizar seu capital, sua entrada em cena no mercado imobiliário comercial introduziu mudanças importantes no modo de funcionamento desse mercado e nas morfologias produzidas (Theurillat, Rérat e Crevoisier, 2015; Sanfelici, 2018).

Apesar de a literatura em estudos urbanos ter estudado com profundidade a expansão da chamada financeirização nos e dos diferentes produtos imobiliários - setor residencial, infraestruturas e imóveis corporativos e comerciais (ver Klink e Barcellos, 2017; Aalbers, 2018) -, um produto imobiliário particular tem chamado menos atenção das pesquisas acadêmicas: o setor logístico. Ademais, ainda há espaço para investigar como os instrumentos financeiros lastreados em diferentes produtos imobiliários inovam, tanto em termos de engenharia financeira, quanto em termos de suas articulações com a produção urbana, adequando-se às expectativas dos grandes investidores e também à conjuntura política e institucional. Nesse sentido, argumentamos que a financeirização de um objeto urbano em específico - o parque imobiliário logístico brasileiro - decorre da convergência de duas forças principais. Por um lado, sustenta-se que a conjuntura da pandemia mundial da Covid-19, ao impedir a mobilidade de pessoas, fortaleceu o setor varejista na sua modalidade e-commerce, impulsionando o crescimento do complexo logístico-imobiliário brasileiro. Por outro lado, averiguamos que, pelo lado da oferta, as sucessivas quedas na taxa de juros contribuíram para a procura dos investidores brasileiros - sejam eles grandes investidores institucionais, sejam pessoas físicas - por investimentos alternativos mais rentáveis, mas, ainda assim, menos suscetíveis às oscilações do mercado de ações. Assim, argumentamos que os fundos de investimento imobiliário (FIls) - veículos de investimento coletivo responsáveis pela captação de recursos de investidores dispersos para aplicá-los no mercado imobiliário - ligados ao setor de logística consolidam-se, ao mesmo tempo, como indutores da expansão do setor logístico-imobiliário brasileiro e como importante "saída" para os investidores brasileiros. 
Tendo em vista a confluência dessas duas variáveis, propomo-nos a investigar os fundos de investimento imobiliário lastreados exclusivamente no setor de logística, buscando compreender como o instrumento contribuiu para a expansão do setor logístico-imobiliário brasileiro nos últimos anos e de que forma as expectativas dos investidores financeiros influenciam nas características morfológicas e na localização dos empreendimentos logísticos. Para tanto, utilizamos como metodologia o mapeamento e a análise de 19 fundos de investimento imobiliários logísticos (FIls-L) existentes atualmente no mercado; análise de materiais de imprensa especializada e consultorias internacionais como Cushman \& Wakefield e Colliers; e entrevistas semiestruturadas com gestores de ativos realizadas entre 2018 e 2020.

0 artigo está dividido em três seções complementares: na primeira, analisamos brevemente o crescimento do setor logístico brasileiro nos últimos meses, conectando o fenômeno à crise sanitária da Covid-19 e ao crescimento do setor varejista; na segunda, realizaremos uma revisão da bibliografia concernente ao tema investigado; e, na terceira, analisaremos os Flls-L a partir das principais características dos empreendimentos e do padrão territorial dos investimentos.

\section{O setor varejista brasileiro, a pandemia da Covid-19 e o crescimento dos fundos de investimento imobiliário}

O setor varejista brasileiro, marcado pela atuação de empresas como Lojas Americanas e Magazine Luiza, passou por um rápido crescimento no último ano. Segundo matéria do jornal Valor Econômico, em 2020, o setor foi responsável por realizar 16 ofertas públicas iniciais de ações ${ }^{1}$ (IPO, na sigla em inglês), o que movimentou cerca de R\$27,3 bilhões. Em apenas 5 meses, a abertura de capital dessas empresas na bolsa de valores do País foi responsável por uma movimentação financeira superior ao que se esperava para o setor para uma década (Mattos, 2020). Para além dos novos IPOs, o varejo brasileiro sofreu uma rápida valorização a partir de abril de 2020 (Boas e Lima, 2020). A título de exemplo, na avaliação de investidores, a Via Varejo, empresa responsável pelas redes Casas Bahia e Pontofrio e administradora do e-commerce Extra, e a Magazine Luiza destacaram-se como as ações favoritas dos investidores no ano de 2020, superando, inclusive, grandes empresas como a Vale, Itaú Unibanco e Bradesco (Goeking, 2021).

Apesar da intensa recessão econômica que atingiu a maioria dos países no contexto da pandemia da Covid-19, apontada, inclusive, como a pior desde a Segunda Guerra Mundial pelo Banco Mundial (ONU News, 2020), o setor varejista internacional registrou um crescimento considerável: vale mencionar, por exemplo, que em 2020 a Amazon superou a Apple como empresa com maior valor de mercado (Pezzotti, 2020), e o Mercado Livre passou por uma valorização no mercado americano de $185 \%$ desde o começo da pandemia (Infomoney, 2021). Os comércios fechados devido às medidas de segurança e a redução das atividades de lazer e trabalho, para conter o espraiamento do vírus, ${ }^{2}$ fizeram as vendas on-line atingirem um patamar nunca visto anteriormente. O chamado "varejo digital" movimentou, até setembro de 2020 , cerca de $\mathrm{R} \$ 100$ bilhões nas plataformas digitais (sites 
e aplicativos) utilizadas pelas redes varejistas. Esse montante é cerca de $78 \%$ maior que no ano anterior (2019). Devido à necessidade de atender a esse contingente cada vez maior de compradores espalhados pelo território nacional, a grande empresa de varejo internacional, Amazon, assim como a brasileira, Magazine Luiza, sinalizaram estar interessadas na compra da estrutura logística atualmente pertencente aos Correios. A compra da rede de logística de caráter nacional aconteceria após a privatização da empresa (Simão, Ribertio e Otta, 2020) e teria o intuito de reduzir os preços e prazos de entregas em regiões mais distantes dos polos logísticos já pertencentes às empresas - estes localizados principalmente na região sudeste do País (Rizério, 2020; Cushman e Wakefield, 2020). Esse movimento em busca da ampliação de infraestrutura logística - tanto de armazenamento como de transporte para acelerar o processo de entrega dos produtos comprados é chamado de movimento last mile (última milha) (Siila, 2021b). Segundo matéria da revista The Economist (2018), as grandes empresas varejistas do mundo, como AliBaba e Amazon, estão investindo maciçamente no setor logístico para promover um serviço mais rápido e eficiente aos seus clientes. As companhias, segundo a matéria, têm atuado a partir de duas principais frentes: 1 ) na mineração de dados dos consumidores para identificar padrões de consumo; e 2) no transporte internacional de produtos, através do investimento em grandes embarcações e aviões. Em 2017, a Amazon criou seu próprio departamento logístico e investiu cerca de 25 bilhões de dólares (o equivalente a $\mathrm{R} \$ 1$ trilhão). No Brasil, a empresa inaugurou, em novembro de 2020, três novos centros de distribuição localizados, respectivamente, nas cidades de Betim (MG), Santa Maria (DF) e Nova Santa Rita (RS) (Infomoney, 2020).

A demanda pela construção de galpões logísticos fortaleceu o desenvolvimento de outra cadeia de valor: a de fundos de investimento imobiliário especializados em ativos de logística. Devido às sucessivas quedas na taxa de juros do País nos últimos anos, os investidores brasileiros têm procurado diversificar suas aplicações no mercado financeiro, procurando ativos mais rentáveis do que aqueles indexados ao CDI. ${ }^{3}$ Nesse contexto, os fundos imobiliários emergiram como uma alternativa de investimento caracterizada por isenção tributária, rentabilidade superior em média aos títulos de renda fixa indexados ao CDI e regularidade de pagamento de dividendos. Esses fundos reúnem recursos financeiros de um conjunto de investidores (que se tornam detentores de frações ideais do veículo) e investem esses recursos em um conjunto de ativos financeiros ou reais. Esses ativos, no caso dos Flls, são propriedades imobiliárias dos mais diferentes tipos, como escritórios, hospitais, shopping centers e galpões logísticos ou, ainda, títulos financeiros lastreados em operações imobiliárias, como os Certificados de Recebíveis Imobiliários (CRIs). Embora regulamentados, no Brasil, em lei aprovada em 1993 (lei n. 8.668 de 25 de junho de 1993), foi, a partir de 2009, que os fundos imobiliários experimentaram um crescimento significativo. Segundo Sanfelici (2017), a aprovação da isenção tributária para os investidores em fundos de investimento imobiliário - um processo que exigiu articulação e negociação entre diferentes atores (ver também Sanfelici e Halbert, 2019) - favoreceu, em grande medida, a criação e distribuição de 
novos fundos para investidores institucionais e pessoas físicas. Essa medida de caráter tributário foi complementada pela normativa n. 472 da Comissão de Valores Mobiliários, aprovada em 2009, que regulamentou diversos aspectos relativos à criação, à administração e à governança de fundos imobiliários, criando um arcabouço regulatório mais sólido para o funcionamento desses veículos de investimento.

Nos últimos 10 anos, os Flls experimentaram um crescimento expressivo: o número de fundos registrados quintuplicou (de 89 para 462), e sua capitalização de mercado cresceu de $\mathrm{R} \$ 5$ bilhões para quase $\mathrm{R} \$ 134$ bilhões (Anbima, 2017; Uqbar, 2020) (ver Figura 1). Com relação ao segmento logístico, apesar de o setor ainda não ultrapassar os segmentos tradicionais de shopping centers e de escritórios, o crescimento de emissões de Flls-L em 2020 é sintomático (ver Figura 2). Nesse sentido, observe-se que a indústria financeira sinaliza claramente que esse mercado será promissor nos próximos anos. Nas palavras de um gestor de Fll: "O mercado logístico segue como uma das principais promessas para investimentos imobiliários em 2021, tanto por seu perfil de risco, quanto pelo potencial de valorização de médio e longo prazo" (Dib, 2021).

Unindo a demanda das empresas pelo desenvolvimento de galpões logísticos com a necessidade de ampliar a oferta de produtos de investimento à disposição de investidores, os gestores de fundos de investimento imobiliário dobraram a aposta no setor logístico durante a pandemia. Durante a pandemia, a criação de Flls especializados no segmento logístico superou a criação de Flls atrelados a outros segmentos imobiliários, como o tradicional de lajes corporativas, e escritórios e, segundo especialistas do mercado, foi a classe de investimento mais "resiliente" ao cenário de crise econômica (Tauhata, 2020; Cotias, 2020; Zonta D'Avilla, 2020).

Nesse contexto, os Flls iniciaram um movimento intenso de desenvolvimento e aquisição de galpões logísticos para a posterior venda de cotas aos mais diversos tipos de investidores. A título de exemplo, cabe mencionar o caso da Vinci Partners que, através de uma parceria com uma desenvolvedora de galpões, pretende lançar um FII em 2021 para

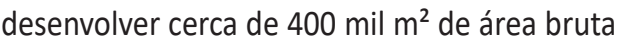
locável ( $A B L$ ), um investimento de $R \$ 1$ bilhão (Investidor Institucional, 2020b); a HSI investimentos que lançou, em dezembro de 2020, um Fll logístico cujo portfólio inicial conta com $429 \mathrm{mil} \mathrm{m}^{2}$ de $A B L$, sendo os cinco ativos em regiões metropolitanas da capital de três estados (São Paulo, Paraná e Minas Gerais), a menos de $35 \mathrm{~km}$ das respectivas capitais (Bertão, 2020); e, por fim, a Global Logistics Properties $(G L P)$, grande empresa desenvolvedora de galpões no mundo, que pretende lançar ainda esse ano um Fll que movimentará $\mathrm{R} \$ 3$ bilhões de reais (Samor, 2020).

Por fim, cumpre observar que o complexo logístico-imobiliário brasileiro aumentou seu estoque de novos parques logísticos em cerca de duas vezes mais do que o registrado em 2019, um acréscimo de 1,1 milhão de $\mathrm{m}^{2}$ (Cushman \& Wakefield, 2020). Segundo relatório da consultoria imobiliária Cushman \& Wakefield (ibid.), do estoque desenvolvido em 2020, 87\% está localizado na região Sudeste, com destaque para o estado de São Paulo, que recebeu 615,5 mil m² e, em particular, o município de Cajamar, que sozinho recebeu 281,1 mil $\mathrm{m}^{2}$. Segundo a empresa e também segundo o relatório da Colliers International (2020), outra importante consultoria imobiliária 
Figura 1 - Crescimento em patrimônio líquido e número de fundos dos Fundos de Investimento Imobiliário (2005-2019)

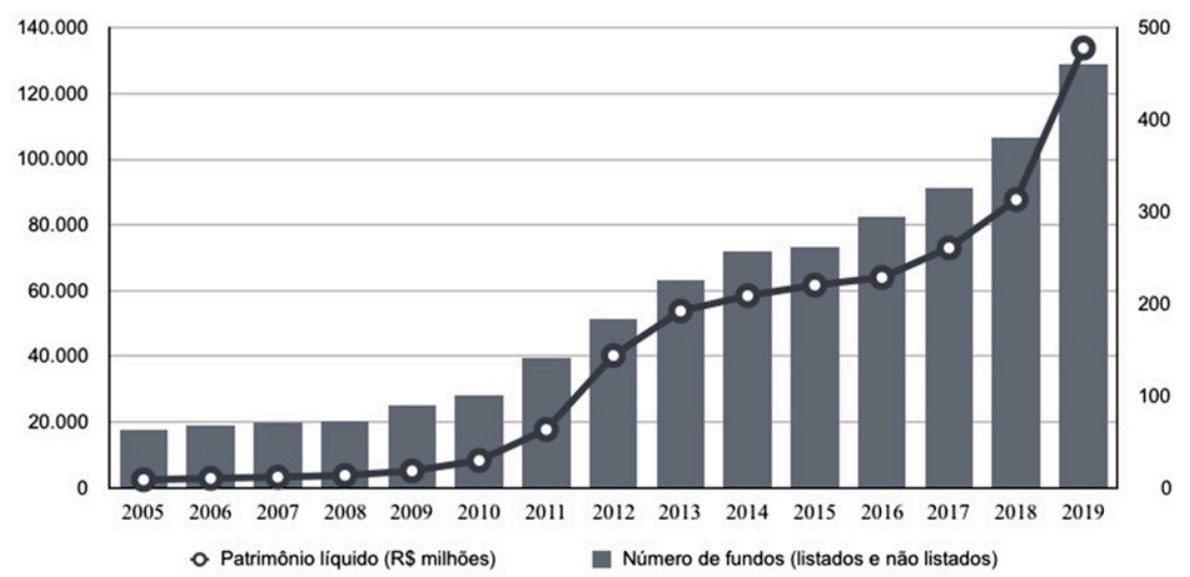

Fonte: confeccionado pelos autores com base nos dados da Anbima (2005 a 2016) e Uqbar (2017 em diante).

Figura 2 - emissões de Fll por tipo de segmento imobiliário (2020)

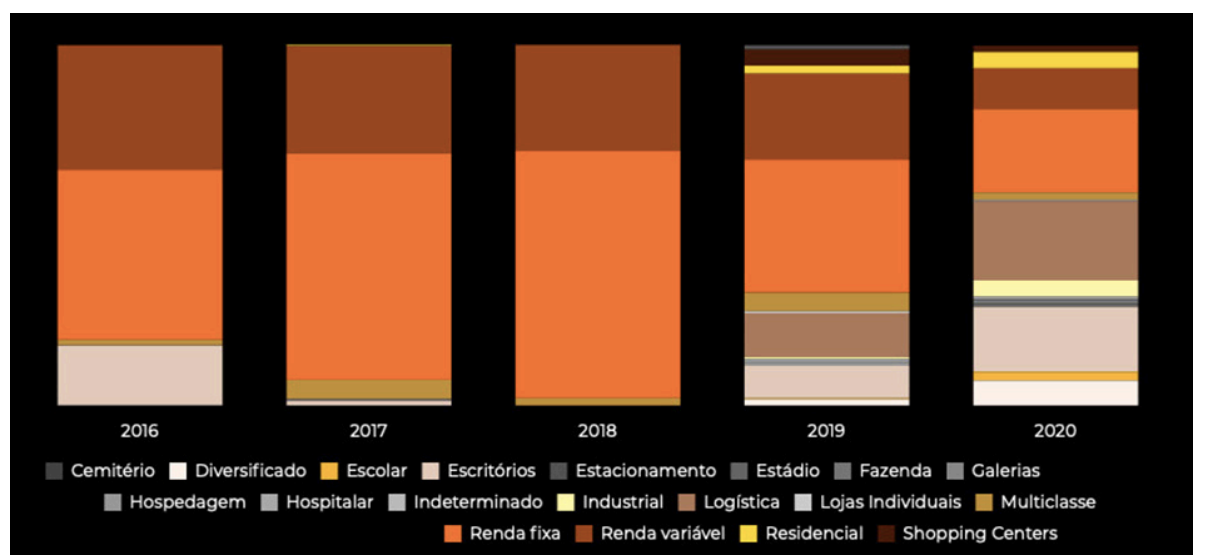

Fonte: Uqbar (2021). 
brasileira, a maior parte dos empreendimentos logísticos lançados foi ocupada por companhias de varejo que tiveram um aumento de demanda impulsionado pelos seus negócios on-line (e-commerce). Atualmente, o estoque imobiliário logístico privado brasileiro conta com cerca de 15 milhões de $\mathrm{m}^{2}$, e, deste total, 9,3 milhões de $m^{2}$ estão localizados no estado de São Paulo, seguido do Rio de Janeiro, com 2,1 milhões de $\mathrm{m}^{2}$.

\section{O imobiliário logístico como produto financeiro: breve revisão}

Conforme salientado anteriormente, uma série de fatores de ordem estrutural foi responsável pela ampliação do complexo logístico-imobiliário brasileiro. Como procuramos desenvolver neste trabalho, os fundos de investimento imobiliário foram responsáveis por unir a demanda aquecida por imóveis logísticos - proveniente, principalmente, dos grupos varejistas que viram suas atividades de e-commerce acelerarem durante a pandemia - com a procura de investidores por novos produtos financeiros que atendam às necessidades dos investidores institucionais e individuais brasileiros. A fim de situar esses processos, analisaremos os estudos que tratam da expansão do setor varejista e o impacto dessa expansão para o mercado imobiliário para, em seguida, analisar os estudos que tratam da participação de investidores institucionais no mercado imobiliário comercial e seus impactos para as cidades.

0 desenvolvimento do e-commerce é analisado pela literatura como um grande influenciador da demanda por bens imóveis de grandes grupos varejistas. Conforme apontam os trabalhos de Gorczynskia e Kooijman (2015), Dixon e Marston (2002) e Hesse (2004), a demanda é alterada tanto quantitativa quanto qualitativamente: há uma decrescente necessidade de estabelecer pontos de comercialização físicos e uma crescente necessidade de expandir espaços imobiliários logísticos. Estudando as possíveis implicações para o setor de supermercados, na Irlanda, com o crescente uso de canais de venda on-line, Gorczynskia e Kooijman (2015) concluem que novos formatos logísticos, considerando sistemas de coleta de pedidos e serviços de entrega em domicílio, serão essenciais para que supermercados se adaptem à realidade do e-commerce. Os autores indicam que, quanto maior o volume de vendas on-line - conforme esperado nos próximos anos -, menor será a necessidade de as redes de supermercados possuírem lojas físicas e maior será a necessidade de adquirirem ou expandirem centros de distribuição para dar apoio a esses serviços. Assim, devido às modificações das estratégias de venda, a configuração da demanda imobiliária desses grandes grupos varejistas passará por intensas modificações nos próximos anos, com a redução da necessidade de imóveis de varejo (lojas) e a incorporação de imóveis de logística, como centros de distribuição e plataformas pick-up. ${ }^{4}$

Dixon e Marston (2002) acrescentam, ao investigar o setor varejista do Reino Unido, duas outras implicações complementares que tangenciam as mudanças ocorridas no varejo com impactos para o mercado imobiliário. Primeiro, os autores apontam que o padrão de compras "geocêntrico", estabelecido entre os compradores e vendedores, passa a ser questionado na medida em que os compradores on-line não precisam mais se dirigir fisicamente 
ao centro de compras mais próximo de suas residências, bastando apertar um botão de seus computadores para comprar itens. Desse modo, os autores sustentam que os varejistas não precisarão mais investir em lojas próximas a centros comerciais e mais bem localizadas, facilitando o acesso a essas terras mais valorizadas para outros grupos econômicos ligados a outras atividades, como bares e restaurantes. A segunda implicação está relacionada com os critérios de avaliação usados pelos locadores (landlords) para avaliar seus locatários no momento que o setor varejista passa a adotar ferramentas de e-commerce. Na visão dos autores, os locadores passarão a avaliar, não somente as vendas e capacidade de gerar receita para o aluguel, mas igualmente a capacidade que o locatário possui de utilizar plataformas on-line. Como veremos adiante, as expectativas dos investidores institucionais são responsáveis por "moldar", inclusive, o perfil dos locatários. Semelhantes resultados são encontrados na pesquisa comparativa entre o Reino Unido e os Estados Unidos realizada por Worzala et al. (2002).

Hesse (2004) dedica-se a analisar o surgimento de um novo setor do mercado imobiliário ligado especificamente ao setor de logística. Para o autor, o surgimento desse submercado é fruto de um processo acelerado de mudança no setor de logística em que as empresas demandam cada vez mais espaço, não somente para estocarem seus produtos, como também para distribuí-los. Nesse sentido, o produto imobiliário logístico sofre uma alteração, não sendo mais necessário produzir armazéns de estocagem - que poderiam estar em regiões mais distantes (também chamadas de gateway), já que não há a necessidade de distribuir com periodicidade uma grande quantidade de bens-, mas sendo, contudo, necessário expandir os centros de distribuição -, estes localizados em áreas que necessitarão de melhor rede de infraestrutura para transportar rapidamente os produtos para os grandes centros. $\mathrm{O}$ autor conclui que essa mudança do tipo de construção de propriedades logísticas atraiu uma grande variedade de investidores institucionais, incluindo fundos de investimento imobiliário (investment trusts), interessados na alta rentabilidade desses investimentos logísticos. Hesse (ibid.) ainda assinala, finalmente, que a entrada desses investidores introduziu mudanças significativas na forma como os produtos imobiliários logísticos são desenvolvidos e geridos: antes da participação desses grupos de investidores e incorporadores, os contratos das propriedades logísticas previam a compra do empreendimento (50 a $70 \%$ dos casos), ao passo que, no modelo de desenvolvimento atual, há um aumento dos contratos de aluguéis e locação (em média 3 a 5 anos de duração); antes as empresas responsáveis pela construção eram majoritariamente nacionais, agora são majoritariamente empresas internacionais contratadas pelos fundos de investimento; anteriormente, o desenvolvimento das propriedades era menos especulativo e com menores ganhos de escala, mas, com a entrada de investidores financeiros, os ganhos de escala no desenvolvimento dos projetos passaram a ser privilegiados, dando origem a empreendimentos logísticos ainda maiores. Finalmente, o autor conclui que a entrada dos investidores financeiros no setor logístico possui impacto direto no planejamento de uso de solo e na provisão de infraestruturas, já que a localização dos grandes centros de distribuição será escolhida e negociada entre os investidores e os agentes políticos locais. Essas 
conclusões são em grande medida reforçadas no estudo de Raimbault (2016), que examina as transformações engendradas pela financeirização do imobiliário logístico na França.

Tais considerações sobre a entrada de investidores financeiros no setor imobiliário logístico dialogam com uma extensa literatura que tem procurado discernir as repercussões da maior presença de instituições financeiras na concepção, produção e gestão de imóveis comerciais - categoria que inclui, além dos imóveis logísticos, ativos como escritórios, shopping centers, agências bancárias, etc. Embora esses estudos tenham raramente abordado exclusivamente os fundos imobiliários logísticos, algumas de suas conclusões são relevantes para refletir sobre o significado da transformação do imobiliário logístico em produto financeiro. Três dentre as conclusões comumente assinaladas na literatura sobre a financeirização do mercado imobiliário comercial são de interesse para os nossos propósitos aqui. A primeira faz alusão ao processo de "externalização" do patrimônio imobiliário de grandes grupos econômicos, incluindo grupos varejistas, para a indústria financeira. A segunda refere-se à seletividade dos investidores financeiros em termos de escolha dos ativos imobiliários em que investem. A terceira remete à capacidade desses investidores em moldar, por meio de suas expectativas de risco e rentabilidade, os atributos específicos dos imóveis e dos projetos em que investem, com implicações importantes para as cidades.

A primeira leitura que a literatura da financeirização traz aponta para a interferência direta dos acionistas no modelo de governança das empresas industriais que abriram seu capital nas bolsas de valores. Essa interferência, na visão de Halbert (2010; 2013), acabou por favorecer e incentivar a ideia de que, para auferir maior rentabilidade, a empresa deveria priorizar sua atividade principal (core business) - por exemplo, no caso de supermercados, a venda dos produtos para o consumidor final - em detrimento de outras atividades secundárias. Nesse sentido, a gestão do patrimônio imobiliário desses grupos passou a ser delegada para a indústria financeira que, na racionalidade dos acionistas, possui uma melhor expertise para gerir imóveis. Os grupos econômicos procederam, assim, a um processo de "externalização" do patrimônio imobiliário, usando frequentemente o mecanismo de sale and leaseback. Nesse processo, a empresa que detém um imóvel (seja um escritório, uma agência bancária, um galpão logístico, etc.) vende esse imóvel para um investidor financeiro (sale) e aluga novamente o próprio espaço (leaseback). Assim, um ativo até então pouco líquido - o imóvel - passa a ser passível de negociação, e o capital oriundo dessa venda pode ser reutilizado em outros investimentos considerados estratégicos à atividade-fim da empresa. Finalmente, esse movimento de "desinteresse" dos proprietários tradicionais de gerir suas propriedades acabou favorecendo, na visão de Halbert (2013), a construção de uma indústria de investimento cujo objetivo é negociar ativos urbanos entre investidores financeiros.

No segundo grupo, encontram-se muitos estudos que focalizaram o mercado imobiliário de escritórios em diferentes países e o papel dos investidores financeiros nesse mercado. As conclusões desses estudos apontam para a forte seletividade dos investimentos realizados por investidores financeiros tanto no que diz respeito ao tipo de ativos selecionados para a carteira, quanto na localização desses ativos. 
Henneberry e Mouzakis (2014) analisam o mercado de escritórios no Reino Unido, observando que as condições em que esse mercado opera contrariam o que seria esperado segundo a teoria econômica convencional, assentada no paradigma neoclássico. Os autores observam que, apesar de a taxa de retorno dos investimentos no interior do País mostrar-se superior àquela observada em Londres, os investidores financeiros continuam a privilegiar essa última cidade em suas escolhas de investimento - cidade que também é a base a partir da qual a maioria deles opera. Os autores utilizam os aportes da economia comportamental para explicar tal aparente paradoxo: segundo a pesquisa, os investidores estariam sob o efeito de um viés heurístico de "familiaridade", em que as opções de investimento que estão próximas (social e territorialmente) são julgadas como mais promissoras, mesmo quando os dados não corroboram tal conclusão (sobre o caso do Reino Unido, ver também Lizieri, 2009 e Byrne, Jackson e Lee, 2013). Halbert (2010) traz conclusões semelhantes a respeito do mercado de escritórios na França, ao diagnosticar um "viés metropolitano" (sobretudo em favor de Paris) nos investimentos realizados por investidores financeiros. 0 autor assinala que tal seletividade se explica, entre outros fatores, pela busca por maior liquidez, bastante prezada pelos mercados financeiros por proporcionar mobilidade aos recursos investidos. 0 autor também acrescenta que o desejo de reduzir custos operacionais de gestão do portfólio favorece a concentração da carteira imobiliária em poucos imóveis de maior escala (edifícios corporativos inteiros), visto que a pulverização em uma carteira imobiliária maior levaria ao aumento dos custos de administração contratual com os locatários. Hebb e
Sharma (2014), por sua vez, investigam a atuação dos fundos de pensão na Califórnia em projetos de revitalização urbana e concluem que os projetos em que os fundos investem "tendem a ser filtrados a partir de uma gama de localizações urbanas [...] de um rol de localizações urbanas e selecionados com base naqueles considerados menos arriscados (tanto financeira quanto politicamente) para o desenvolvimento" (ibid., p. 492).

No caso brasileiro, alguns estudos também assinalam a presença de lógicas de investimento semelhantes. Sanfelici (2018) analisa os fundos de investimento imobiliários no Brasil em todos os segmentos de investimento e observa, igualmente, forte concentração territorial, nesse caso na capital paulista e, em menor grau, na capital fluminense, além de preferência por ativos de maior metragem, como lajes corporativas. A explicação para tal concentração territorial encontra fundamento a partir das lógicas financeiras de controle de custo, estabilidade dos fluxos de rendimento esperados, maior liquidez de revenda e estabilidade dos contratos de locação dos imóveis. Do ponto de vista urbano, observa-se que tal seletividade implica dinâmicas de exclusão de atividades consideradas menos rentáveis para os investidores financeiros (ver também Sanfelici e Halbert, 2019). Tal estudo é complementado pelo artigo de Santoro e Rolnik (2017), que faz uso do conceito de complexo imobiliário-financeiro para investigar a entrada de investidores estrangeiros no mercado imobiliário de São Paulo. As autoras dedicam-se a mapear e analisar os padrões de investimento imobiliário tanto de empresas incorporadoras globais quanto de fundos de investimento imobiliário. No âmbito destes últimos, o estudo verifica a existência de padrões territoriais que variam 
conforme os ativos. No caso dos ativos de edifícios corporativos, a concentração na região da avenida Faria Lima e arredores é notável, confirmando a tendência de expansão do centro financeiro da cidade de São Paulo já observada em Fix (2007). 0 estudo também destaca uma correlação entre as obras de novos projetos logísticos, majoritariamente concentrados ao longo do Rodoanel (SP), e as remoções de moradores de baixa renda na Região Metropolitana de São Paulo.

Alguns estudos dirigiram um olhar mais detido às repercussões urbanas dos investimentos conduzidos por esses atores. As pesquisas de Theurillat e Crevoisier (2013) e Guironnet, Attuyer e Halbert (2016), por exemplo, demonstram como as expectativas de investimento da comunidade financeira formatam as qualidades urbanísticas de projetos de renovação urbana, respectivamente na Suíça e na França. No caso francês, de um projeto de renovação urbanística no município de Saint-Ouen, na grande Paris, essas expectativas condicionaram, em grande medida, a tipologia dos imóveis comerciais, incluindo aspectos como tamanho mínimo das lajes, especificações construtivas de acordo com padrões internacionais, localização em relação ao transporte público, etc., todos buscando adequar os empreendimentos construídos às necessidades de empresas ocupantes de grande porte (blue-chip), preferidas pelos fundos de investimento. No caso suíço, Theurillat e Crevoisier (2013) ressaltam como a presença de investidores financeiros modifica o processo de negociação para a consecução de projetos urbanos. Os autores enfatizam a necessidade de atores locais que trabalhem para "ancorar" o capital financeiro no território, o que envolve negociações com atores com expectativas e racionalidades diferentes. Aveline-Dubach (2016), por sua vez, analisa os modelos de gestão dos trusts de investimento imobiliário (Reits) em Hong Kong - que guardam semelhança com os fundos imobiliários brasileiros. Em consonância com as pesquisas já revisadas anteriormente, a autora observa que os Reits tendem a concentrar seus investimentos em um pequeno número de localidades, principalmente centros financeiros ou áreas centrais. Para além dessa dinâmica espacial, porém, a autora verificou que, em suas práticas de gestão do estoque imobiliário, os fundos costumam empregar estratégias agressivas de aumento de aluguel, que envolvem a renovação de imóveis antigos para atrair um novo perfil de inquilino e a redução dos prazos dos contratos de locação para rentabilizar ainda mais os ativos que detêm em carteira. Essa seleção de inquilinos com características específicas, como vimos anteriormente, também é observável como tendência no setor de logística e envolve, como mostrou Dixon e Marston (2002), a disposição do locatário em utilizar plataformas on-line de e-commerce.

Em síntese, a literatura existente sobre a financeirização do mercado imobiliário comercial aponta para transformações importantes nas lógicas que presidem as decisões de investimento e de gestão do estoque imobiliário, resultando em padrões de investimento bastante seletivos tanto do ponto de vista da localização quanto no que se refere ao perfil construtivo dos imóveis. É preciso reconhecer, porém, que cada um dos segmentos imobiliários englobados sob a categoria de "imobiliário comercial" suscita questões diferentes no que tange à conexão (e, eventualmente, tensão) existente entre as expectativas de rentabilidade manifestadas pelos investidores financeiros e as 
transformações no uso do solo urbano que devem ser levadas a cabo para gerar os fluxos de renda necessários para valorizar esses capitais. Tendo em vista a necessidade de conhecer melhor essas especificidades, dirigimos nossa atenção para a participação dos fundos imobiliários brasileiros no segmento de logística.

\section{Os fundos de investimento imobiliário logísticos: caracterização e análise}

Nesta seção tratamos especificamente dos fundos de investimento imobiliário logísticos a partir de suas características principais: sua data de criação, quantidade de cotas e cotistas, valor agregado do instrumento, vacância do FIl, tipo de gestão (ativa ou passiva). ${ }^{5}$ Além disso, concentramo-nos nos empreendimentos geridos por esses instrumentos, analisando: ano de construção do imóvel, localização, tipo do empreendimento (galpão isolado, galpão $A+$, etc.), principais inquilinos, média de duração dos contratos, $A B L$ total, incorporador do empreendimento, etc. Outras características arquitetônicas e de funcionamento dos empreendimentos também foram analisadas separadamente, como: se há sistema de segurança 24 horas, número de docas disponível, etc. Esse conjunto de dados foi obtido através da análise de 19 Flls-L e resultou em 101 propriedades logísticas. ${ }^{6}$ A amostra foi selecionada a partir do tamanho do patrimônio gerido pela gestora dos veículos de investimento. Selecionamos as 15 maiores gestoras ${ }^{7}$ de Flls que, conjuntamente, concentram cerca de $70 \%$ do total investido por todas as gestoras do mercado (cerca de $\mathrm{R} \$ 145,5$ bilhões), um valor de aproximadamente $\mathrm{R} \$ 103$ bilhões (Anbima, 2020). Como metodologia, realizamos a análise documental dos Flls-L, utilizando, principalmente, as informações agregadas disponibilizadas em sites e canais direcionados especialmente para o público investidor, como o Clube $\mathrm{FII},{ }^{8}$ bem como os relatórios trimestrais e anuais de Flls e publicações de fatos relevantes disponibilizados pela CVM (Comissão de Valores Mobiliários). Complementarmente, analisamos artigos de jornais, como Valor Econômi$c o$, e veículos de comunicação especializados no setor financeiro, como InfoMoney. Também recorremos à análise de materiais de empresas e associações especializadas em investimento e direcionadas especialmente para o público investidor em Flls. Fizeram parte dessa estratégia a assinatura de newsletters e o acompanhamento de canais de notícias e lives abertas ao público das seguintes instituições: das consultorias imobiliárias Cushman \& Wakefield e Colliers; da Siila Brasil, empresa especializada em divulgar e fornecer informações do mercado financeiro; do GRI Club, clube especializado na análise do mercado imobiliário em nível internacional; do Clube FII, entre outras. Finalmente, utilizamos, como fonte complementar, as entrevistas semiestruturadas realizadas nos anos de 2018 a 2020 que tiveram como público-alvo gestores de fundos de investimento imobiliário, consultores imobiliários, grandes investidores institucionais interessados em Flls, como fundos de pensão, e empresas concorrentes do setor, como property companies. ${ }^{9}$

A análise dos Flls-L selecionados mostrou que somente esses 19 Flls concentram uma $A B L$ total de $4.566 .387 \mathrm{~m}^{2}$, dos quais mais da metade está concentrada no estado de São Paulo (2.575.065 m²), seguida do estado do Rio de Janeiro, com 510.603 m2 de ABL. 
Esse resultado representa cerca de $30 \%$ do total do parque privado de logística no Brasil, $28 \%$ do total de ABL em São Paulo e $24 \%$ do total do estado do Rio de Janeiro (Cushman e Wakefield, 2020). Essa concentração do parque logístico privado brasileiro nas mãos de Flls ganhou impulso recentemente, como consequência do crescimento do setor varejista e das constantes quedas das taxas de juros, tendo em vista que 10 dos 19 Flls-L foram criados a partir de 2018. Essa recente concentração da rede logística brasileira sob encargo dos fundos de investimento imobiliário sinaliza a importância de compreender a atuação desse agente no atual desenvolvimento do setor logístico brasileiro, bem como discernir os impactos socioespaciais decorrentes desse envolvimento do setor financeiro com a promoção de infraestruturas logísticas.

Um primeiro ponto que precisa ser analisado detidamente diz respeito às preferências de investimento dessa classe de investidores financeiros. Nossa análise mostrou que os Flls-L brasileiros possuem uma relevante preferência por galpões novos - 50, dos 101 imóveis que compõem a carteira dos fundos analisados, foram construídos a partir do ano de 2010 e 20 nos anos 2000 - e localizados no Sudeste (81 empreendimentos), Sul do País (10 empreendimentos) e Nordeste ( 2 empreendimentos) ${ }^{10}$ (ver Figura 3). Uma alta concentração é observada no estado de São

Figura 3 - Estoque imobiliário logístico controlado por fundos de investimento imobiliário (FIls) nas regiões Sudeste e Sul - abril de 2021

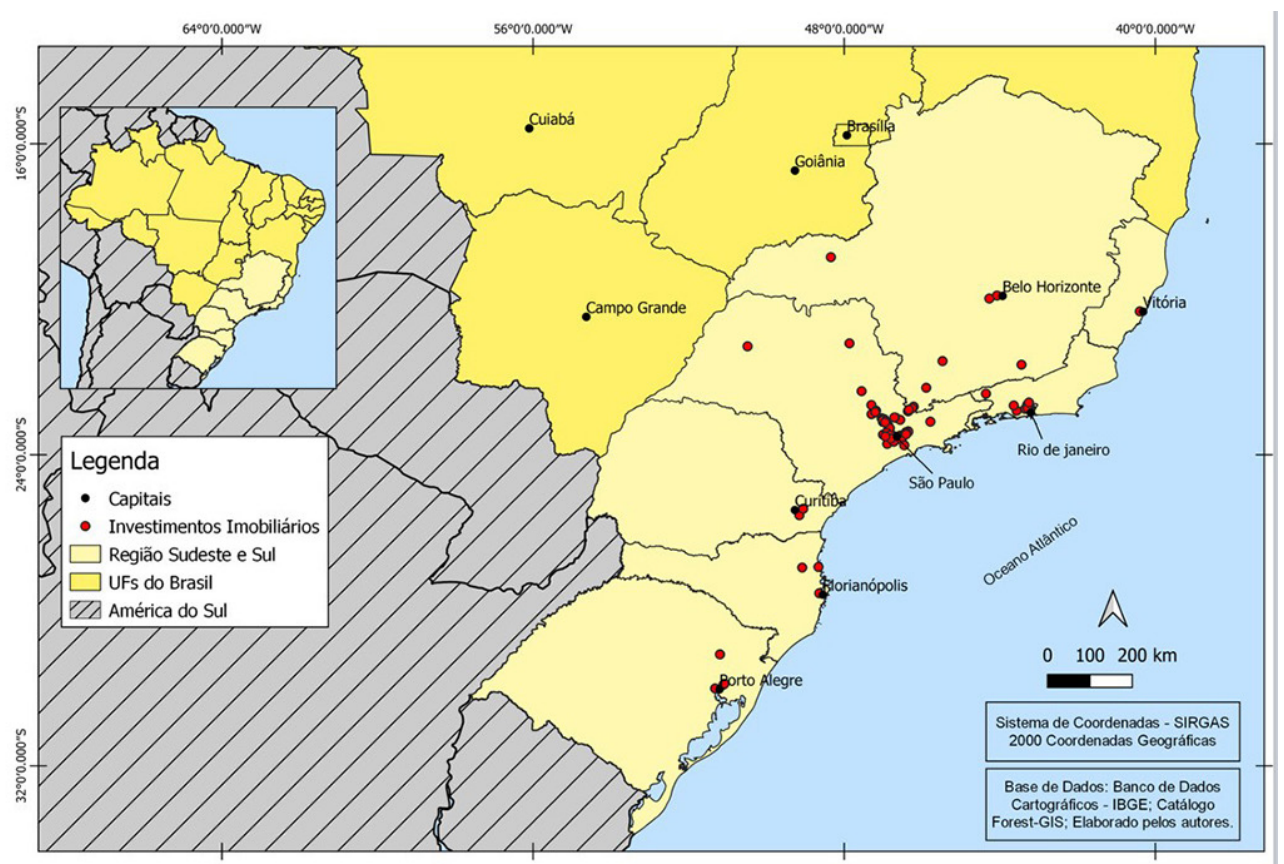

Fonte: dados compilados pelos autores, a partir de relatórios dos Flls-L e das informações disponíveis em Clubes Flls 
Paulo (49 galpões), em cidades como Cajamar (7 galpões), Jundiaí (5 galpões) e São Paulo (5 galpões). Ainda com relação às preferências de investimento desse grupo de investidores, constatamos que 37 empreendimentos logísticos são do segmento "galpão isolado" - comumente sem segurança 24 horas, sistemas de sprinklers para incêndios e geradores - e 29 são classificados como galpões $\mathrm{A}$ ou $\mathrm{A}+$, com características arquitetônicas e de funcionamento que garantem maior segurança para o inquilino, como segurança 24 horas e sistemas de sprinklers para incêndios.

É relevante observar que as preferências de investimento, em termos de localização e em favor de dois segmentos de galpões distintos, revelam importantes padrões que geram impactos significativos na forma como o ambiente construído urbano é produzido. Com relação à distribuição espacial dos empreendimentos, a localização na região Sudeste, especialmente concentrada no estado de São Paulo, é sintomática. Segundo entrevistados, a concentração dos Flls no estado de São Paulo é explicada pelas suas características demográficas e econômicas que permitem uma boa previsibilidade de resultados financeiros, esta atrelada, como veremos, ao perfil e à permanência dos inquilinos que procuram centralizar suas atividades na principal economia do País. Dentre essas características demográficas e econômicas, destacam-se: 1) a densidade e qualidade da malha de infraestrutura rodoviária, que facilita a circulação dos produtos armazenados para o consumidor final; e 2) a proximidade dos principais mercados consumidores. Destaque-se, nesse ponto, a posição estratégica dos ativos de FII-L ao longo das principais rodovias e entroncamentos rodoviários que ligam o interior do estado de São Paulo com a capital paulista, bem como esta última com o Rio de Janeiro e Belo Horizonte (ver Figura 4). Essa área de mais de 30 milhões de habitantes, que compreende as Regiões Metropolitanas de São Paulo, Campinas, da Baixada Santista, bem como aglomerados urbanos de expressão como Sorocaba e São José dos Campos, é caracterizada por uma demanda por galpões bastante alta e que, por isso, tem despertado o interesse de agentes incorporadores e, em uma segunda etapa, dos fundos imobiliários como investidores finais em busca de fluxos de rendas urbanas.

Com relação à característica dos empreendimentos, foram destacados acima dois tipos principais de galpões geridos por Flls-L: 0 chamado "galpão isolado" e os galpões com alto padrão construtivo, classificados como $\mathrm{A}+\mathrm{e}$ A. $O$ interesse em possuir em carteira galpões isolados pode ser explicado pela facilidade - e, portanto, baixo custo - de gestão desse tipo de galpão, já que as atividades ligadas à manutenção e à gestão diária da propriedade ficam sob incumbência do inquilino ou da empresa terceirizada por ele contrata. Além disso, o investimento em galpões $A$ e A+ sinaliza a preferência dos investidores Flls por objetos imobiliários de alto padrão, que, por sua vez, geram alta taxa de ocupação e, portanto, fluxo de caixa estável para os investidores finais (Sanfelici e Halbert, 2019). Essa mescla entre os dois tipos de galpões que compõem a carteira dos Flls-L demonstra de maneira clara a estratégia dos Flls de distribuir dividendos regularmente, assegurando, assim, a permanência de cotistas pessoas físicas, $80 \%$ do total de investidores (Uqbar, 2020), que buscam no instrumento uma segurança típica de aplicações conservadoras em renda fixa (Tauhata, 2019; Cotias, 2019). No caso dos galpões isolados, a escolha 
Figura 4 - Estoque imobiliário logístico controlado por fundos imobiliários na macrometrópole paulista - abril de 2021

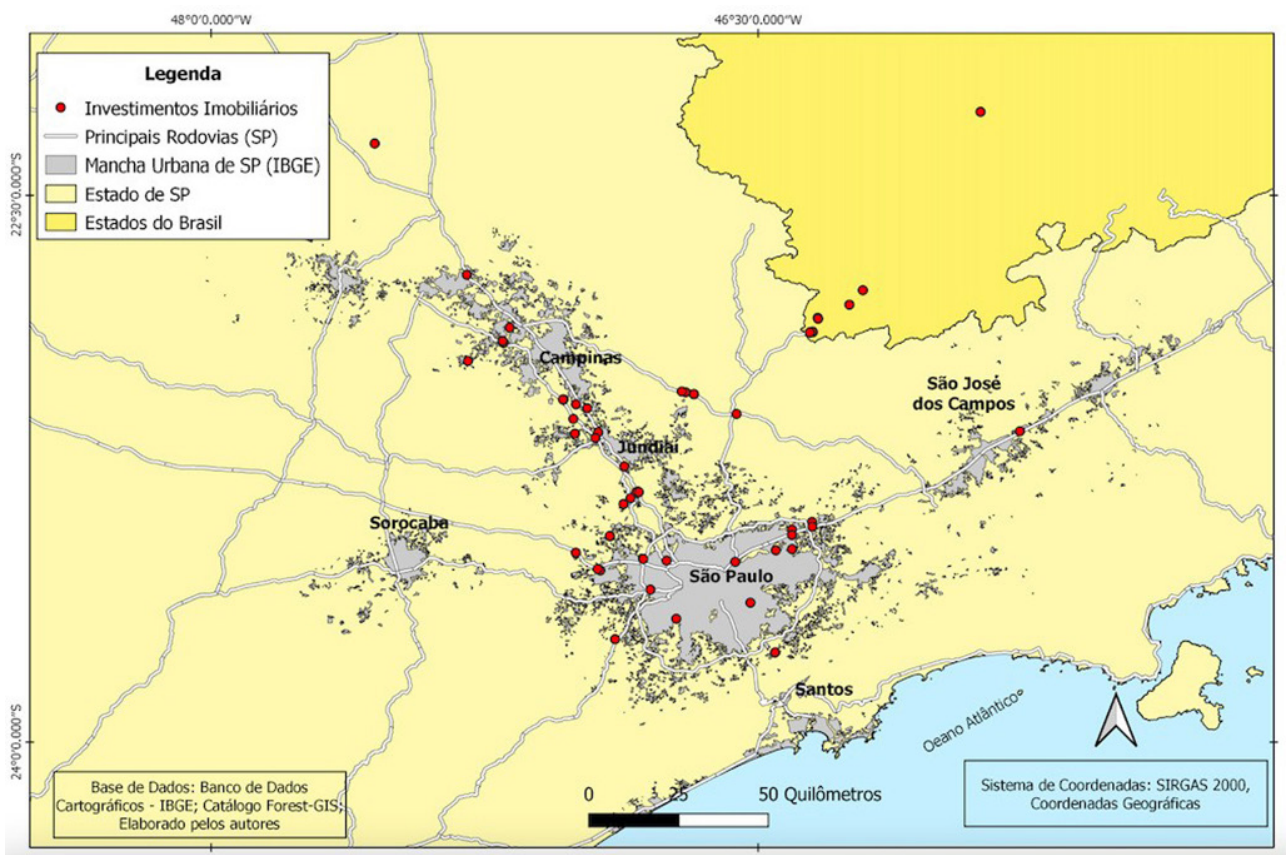

Fonte: dados compilados pelos autores, a partir de relatórios dos Flls-L e das informações disponíveis em Clubes Flls.

dos investidores ainda é bastante determinada pela escassez de ativos de maior qualidade no mercado, uma lacuna que tem sido, aos poucos, suprida com o desenvolvimento de condomínios logísticos mais sofisticados ${ }^{11}$ (Quintão, 2021). No caso dos galpões classificados como alto padrão, a escolha feita pelos investidores reflete o desejo dos gestores de fundos imobiliários por ativos que possam atrair inquilinos considerados mais estáveis, como grandes empresas nacionais e multinacionais que estejam abertas a firmar contratos de locação atípicos de longo prazo. Essa estratégia passiva de gestão, ou seja, que não prevê grandes riscos de desenvolvimento, manutenções e expansões, conforme ressalta um dos entrevistados para este trabalho, assinala a diferença dos Flls e relação a outros investidores que atuam no mercado imobiliário comercial, como property companies - estas mais inclinadas a assumir riscos de incorporação.

Conforme ressaltamos, a "qualidade" do inquilino é fator fundamental para garantir a estabilização da cota em um patamar elevado e, portanto, garantir rentabilidade atrativa aos Flls. Nesse sentido, analisamos o perfil dos três maiores inquilinos de cada um dos imóveis na carteira dos fundos imobiliários, a partir do ramo de atuação da empresa locatária e da duração média dos contratos firmados. A Tabela 1 , que registra as empresas inquilinas segmentadas por ramo de atuação, ${ }^{12}$ confirma, em 
grande medida, que os Flls buscam selecionar empresas que possuem fluxo de caixa estável e uma boa avaliação (rating) de crédito, garantindo, para os proprietários desses ativos, um fluxo de caixa previsível e alto. De um universo de 303 inquilinos e contratos analisados, ${ }^{13} \mathrm{o}$ setor que concentra mais contratos é o varejista (44 contratos de aluguel), tendo como locatárias empresas como Magazine Luiza e Via Varejo, seguido automobilístico e peças automotivas (38 contratos), com empresas como Fiat, Renault e Mercedes Benz. A duração média dos contratos é de 3.691 dias, o equivalente a 10 anos, e a maior parte dos empreendimentos conta somente com um inquilino locatário ou entre 10 e 30 inquilinos, demonstrando que, quando há necessidade de exclusividade, o padrão de locação é unitário; e, quando não há, os galpões costumam abrigar um grande número de empresas atuantes. A análise mostrou que, quando há contrato com somente uma empresa, os inquilinos são do setor automobilístico e peças automotivas, o que tem relação com o tipo de produto produzido.

Os resultados que dispomos permitem apontar algumas conclusões acerca da conversão do imobiliário logístico em produto financeiro e suas implicações territoriais. Um primeiro ponto a ser observado é que esse fenômeno decorreu da convergência de pelo menos quatro fatores, que ganharam força ao longo da última década e se aceleraram nos últimos anos: 1) as transformações de longo prazo na área de tecnologia da informação, somadas à pandemia de Covid-19 como elemento catalisador do e-commerce, reforçaram a demanda de empresas de diferentes segmentos por espaços logísticos em pontos estratégicos do território, de modo a abreviar o tempo de entrega dos produtos e, assim, acelerar o tempo de giro dos capitais; 2 ) o desejo de maior flexibilidade contratual das empresas, diante das incertezas e volatilidade do cenário econômico, favoreceu a opção pela locação, em vez da aquisição, de galpões logísticos, criando um mercado de investimento para esses ativos imobiliários; 3 ) a queda sistemática da taxa básica de juros a partir de 2017 tem aquecido a demanda, da parte de investidores individuais e institucionais, por produtos financeiros novos e mais rentáveis, como alternativa aos títulos da dívida pública, cuja rentabilidade sofreu drástica redução; e, finalmente, 4) a maturação de uma indústria financeira brasileira que, por meio do emprego de tecnologias da informação e evoluções normativas, tem conseguido criar e distribuir novos produtos de investimento para uma gama de investidores pequenos e médios, que antes dispunham de poucas opções de aplicação de recursos.

Do ponto de vista das transformações urbano-territoriais que são induzidas pelo maior protagonismo de investidores financeiros sofisticados, como os fundos imobiliários, observamos que as escolhas de investimento desses atores são direcionadas para ativos que proporcionam um fluxo de caixa estável ao fundo e, consequentemente, uma distribuição regular de dividendos aos cotistas. Isso se traduz, em termos de características dos imóveis, em um universo restrito de galpões logísticos de alto padrão, localizados nas regiões mais dinâmicas do Brasil e cujos locatários são predominantemente empresas grandes, especialmente, as varejistas. Nesse sentido, a indústria financeira pouco tem atuado no sentido de pulverizar o capital que gerencia e investe para além das regiões mais desenvolvidas do Brasil, tampouco tem procurado diversificar o perfil dos ativos investidos - ainda que a mobilidade 
Tabela 1 - Empresas inquilinas dos Fundos de Investimento Imobiliário logísticos (2021)

\begin{tabular}{|c|c|}
\hline Setor de atuação e empresa locatária & Quantidade de contratos \\
\hline \multicolumn{2}{|l|}{ Artigos esportivos } \\
\hline Centauro & 10 \\
\hline Netshoes & 14 \\
\hline \multicolumn{2}{|l|}{ Bebidas } \\
\hline Ambev & 1 \\
\hline Spal & 10 \\
\hline \multicolumn{2}{|l|}{ Eletroeletrônica e informática } \\
\hline Foxconn & 14 \\
\hline IBM & 8 \\
\hline \multicolumn{2}{|l|}{ Materiais de construção } \\
\hline Leroy Merlin & 15 \\
\hline \multicolumn{2}{|l|}{ Metalúrgica } \\
\hline Brinox metalúrgica & 1 \\
\hline \multicolumn{2}{|l|}{ Petroquímico } \\
\hline Braskem & 4 \\
\hline \multicolumn{2}{|l|}{ Produtos médicos e hospitalares } \\
\hline Cremer S.A. & 18 \\
\hline \multicolumn{2}{|l|}{ Veículos e peças } \\
\hline Fiat Chrysler & 8 \\
\hline Renault Nissan Brasil & 1 \\
\hline Volkswagen Man & 8 \\
\hline Nakata automotiva S.A. & 18 \\
\hline Mercedes Benz Brasil & 3 \\
\hline \multicolumn{2}{|l|}{ Alimentos } \\
\hline BRF S.A. & 18 \\
\hline Natural one & 10 \\
\hline \multicolumn{2}{|l|}{ Comércio varejista } \\
\hline Via varejo & 15 \\
\hline Grupo Pão de Açúcar (GPA) & 15 \\
\hline Grupo Magazine logística & 14 \\
\hline \multicolumn{2}{|l|}{ Papel e embalagem } \\
\hline Brasilata & 10 \\
\hline Rigesa Westrock & 10 \\
\hline \multicolumn{2}{|l|}{ Energia solar } \\
\hline Renovigi & 1 \\
\hline \multicolumn{2}{|l|}{ Química e petroquímica } \\
\hline Braskem & 3 \\
\hline Sem informações / diversos & 73 \\
\hline Total & 302 \\
\hline
\end{tabular}

Fonte: fatos relevantes (CVM) e Clube FII. 
e a fluidez do capital no território sejam frequentemente reivindicadas como uma das vantagens à economia proporcionadas por mercados financeiros bem desenvolvidos. Acrescente-se que a preferência de investidores por um perfil de galpões mais sofisticados e, por conseguinte, o foco dos incorporadores na construção desse tipo de imóveis, restringem oportunidades de locação para empresas menores e de setores não oligopolizados da economia, incapazes de arcar com o custo elevado de locação. Essa preferência é igualmente encontrada no caso dos Flls cujo foco é o segmento de lajes corporativas, como mostram as análises anteriores de Sanfelici (2018) e Sanfelici e Halbert (2019).

\section{Os objetos urbanos da financeirização: apontamentos finais}

A breve análise aqui empreendida acerca dos fundos imobiliários logísticos ressaltou a complementaridade e sinergia entre duas dinâmicas de reestruturação econômica. De um lado, profundas transformações em curso na economia vêm fortalecendo e tornando mais estratégicas, para as empresas de diversos setores econômicos, as atividades logísticas de armazenamento e, principalmente, distribuição. Com efeito, Coe, Dicken e Hess (2008) sustentam que, com a complexidade e a extensão geográfica das redes globais de produção e a necessidade de coordenar e integrar as diferentes operações da cadeia de valor, as atividades logísticas tornaram-se centrais para as estratégias empresariais. Argumentamos que a pandemia de Covid-19, ao fortalecer tendências já existentes, como o comércio digital, acelerou a transição para um modelo de logística mais flexível, em que as empresas reconfiguram suas implantações no território em reação às alterações nas tendências de mercado. Mais do que isso, a pandemia deflagrou uma corrida por espaços logísticos, suscitando um rápido aumento dos anúncios de novos projetos logísticos para atender a essa demanda.

De outra parte, os investidores financeiros, dispondo de uma infraestrutura complexa para a criação e distribuição de novos produtos imobiliário-financeiros que amadureceu ao longo da década de 2010 (Sanfelici e Halbert, 2019), foram bastante eficazes em tirar proveito das circunstâncias para extrair rendas imobiliárias a partir da posse de ativos estratégicos, como os ativos de logística. Com a queda da taxa de juros, as principais gestoras de recursos do País captaram, em 2019 e 2020 principalmente, um volume substancial de recursos que foi direcionado para a aquisição de outras categorias de imóveis comerciais, aptas à geração de rendas imobiliárias atreladas ao funcionamento de uma cadeia de valor distinta daquelas que sustentam a ocupação de escritórios corporativos, comumente utilizados como lastro nos instrumentos financeiros. Essa procura por extração de renda, não em vão, é bastante seletiva, como vimos, uma vez que a escolha dos ativos imobiliários atende a critérios particulares de risco e retorno convencionados pela indústria financeira.

A busca da ampliação da rede logística, somada à alta concentração de investimento da indústria financeira nesse ativo em específico - cerca de $30 \%$ da rede logística privada brasileira - repercute, ainda, em uma mudança sintomática na estrutura de posse 
desse produto imobiliário. A elevada concentração de investimento de FII-L reverbera desigualdades em toda sua cadeia de concepção e funcionamento: desde o consumidor final da mercadoria - devido à distribuição desigual dos galpões logísticos pelo território brasileiro - até as empresas ocupantes - pelo perfil de inquilino altamente seletivo selecionado pelos Flls-L. Os critérios seletivos de investimento em logística, ainda, extrapolam as fronteiras do setor, recaindo fortemente na própria dinâmica econômica e territorial das cidades que abrigam esses investimentos. É caso concreto dessa situação o município de Cajamar (SP), que possui sua atividade econômica - incluindo oferta de empregos e desenvolvimento de atividades meio - altamente dependente da atividade logística da região. Esse caso evidencia como os investimentos realizados por investidores institucionais em um determinado momento formatam a estrutura econômica e territorial das cidades, reforçando, assim, as "competências" e as vantagens locacionais já consolidadas (em uma trajetória de path dependence) e propagando desigualdades socioespaciais.

Mais análises, contudo, precisam ser desenvolvidas para entender como as rápidas transformações na atividade logística - a perda de importância das atividades de armazenagem em prol das atividades de distribuição, a racionalização da gestão dos estoques para agilizar o tempo de manuseio das mercadorias, o desenvolvimento do e-commerce, o crescimento do setor varejista e a sua oligopolização, etc. - abrem oportunidades para a indústria financeira capturar rendas imobiliárias e, no sentido inverso, como essas práticas de investimento financeiro, e as concepções de risco e retorno que lhes são subjacentes, afetam a qualidade e a localização do estoque imobiliário logístico produzido e repercutem no ordenamento do território. Nesse sentido, é preciso atentar para o fato de que a financeirização ganha contornos diferenciados conforme o segmento imobiliário que se analisa. Assim, uma análise mais detida das forças que condicionam a demanda e a oferta de imóveis em um determinado segmento é uma condição fundamental para entender as estratégias de captura de renda dos investidores financeiros ao direcionar recursos para o imobiliário. Apontamos, ademais, a necessidade de estudos de casos comparativos que busquem compreender, de maneira mais atenta, a financeirização do parque imobiliário logístico a partir de contextos locais. Finalmente, como o desenvolvimento da rede logística depende fortemente da rede de infraestrutura disponível no entorno dos galpões para possibilitar uma vazão rápida dos produtos armazenados, cabe avaliar, em estudos futuros: 1) a força exercida pelos fundos de investimento imobiliário na articulação da provisão de bens de infraestrutura e, também, a articulação envolvendo atores locais para atrair e desenvolver esses empreendimentos logísticos; e 2) o papel do Estado no estímulo ao desenvolvimento de determinados projetos de infraestrutura e logísticos e à participação privada nesses investimentos e como essa provisão privada de infraestruturas favorece a valorização (e a concentração) dos ativos imobiliários logísticos e não logísticos em determinadas regiões do País. 


\section{[I] https://orcid.org/0000-0002-0074-5622}

Universidade Federal Fluminense, Instituto de Geociências, Programa de Pós-Graduação em Geografia. Niterói, RJ/Brasil.

mairamagnani@uol.com.br

\section{[II] https://orcid.org/0000-0002-8292-5503}

Universidade Federal Fluminense, Instituto de Geociências, Departamento de Geografia, Programa de Pós-Graduação em Geografia. Niterói, RJ/Brasil.

danielsanfelici@gmail.com

\section{Nota de agradecimento}

Agradecemos ao Lincoln Institute of Land Policy e à Fundação Carlos Chagas Filho de Amparo à Pesquisa do Estado do Rio de Janeiro (Faperj) pela bolsa de mestrado concedida, aos membros do grupo NUPACT pela leitura e comentários e aos alunos Guilherme Muniz Filho, Tiago Carbone do Nascimento e Calvin Monteiro Borges pelo essencial auxilio na coleta dos dados. Finalmente, agradecemos aos revisores anônimos pelas valiosas contribuições.

\section{Notas}

(1) As seguintes empresas realizaram ofertas públicas em 2020 (entre as já concluídas e em andamento): empresa Quero-Quero (materiais de construção); D1000 (farmácias); Pague Menos (farmácias); Grupo Soma (varejo de moda); Petz (produtos e serviços para animais de estimação); Track\&Field (moda esportiva); Grupo Mateus (varejo alimentar); Companhia Sulamericana de Distribuição (varejo alimentar); Nissei (farmácias); Pernambucanas (varejo de moda, cama, mesa e banho); Tok\&Stok (varejo de móveis, decoração e cama, mesa e banho); Kalunga (varejo de material de escritório e papelaria); Havan (Ioja de departamento); Le biscuit (loja de departamento); Melliuz (empresa de cashback e cupons); Enjoei (plataforma de marketplace).

(2) Em maio de 2020, uma série de medidas para conter a pandemia foi iniciada pelos governos estaduais, como proibição de viagens, suspensão de eventos, shows, aulas, etc. Para as medidas adotadas em cada estado, ver: https://g1.globo.com/bemestar/coronavirus/ noticia/2020/03/15/coronavirus-como-sera-a-segunda-feira-em-cada-estado-apos-medidaspara-conter-a-pandemia.ghtml.

(3) O CDI (Certificado de Depósito Interbancário) é a principal referência (benchmark) de rentabilidade das aplicações de renda fixa. Por refletir o juro médio das transações financeiras interbancárias, a chamada "taxa CDI" indica a taxa básica de juros na economia, sendo, portanto, um dos principais indexadores de diferentes aplicações de renda fixa (títulos do tesouro; letras de crédito imobiliário; letras de crédito do agronegócio, entre outras). 
(4) Plataformas pick-up são aquelas para onde o comprador se dirige, geralmente com seu carro, e coleta suas mercadorias compradas on-line. A vantagem desse centro está relacionada ao seu pequeno porte e a possibilidade de contar com um número reduzido de empregados para mantê-lo.

(5) Gestão ativa é aquela na qual o gestor do Fll analisa periodicamente a formação da sua carteira de ativos no intuito de modificá-la, seja pela inserção de novas propriedades ou pela venda das propriedades já adquiridas que não estão em conformidade com a meta financeira e os objetivos do fundo. Na gestão passiva, por sua vez, o gestor possui uma postura mais passiva com relação à carteira de empreendimentos, procurando não vender ou adquirir novas propriedades no longo prazo. Nesse caso, o custo de gestão do instrumento é reduzido, já que não há a necessidade de um monitoramento constante.

(6) É importante ressaltar que, dentro desse universo, há a expansão de galpões logísticos. As expansões são contabilizadas como uma propriedade/empreendimento, pois elas são tratadas dessa forma nos relatórios e dados utilizados.

(7) BTG Pactual; Kinea Investimento LTDA; Rio Bravo Investimentos LTDA; XP Asset Management; Credit Suisse; Votorantim Asset; BRL DTVM; Hedge Investments; BRPP Gestão de Produtos Estruturados; Oliveira Trust DTVM; Modal; Vinci Partners; Ourinvest; HSI Hemisfério Sul Investimentos S.A.; RBR Gestão de Recursos. Esse rol de gestoras pode emitir tanto Flls listados na bolsa de valores como Flls não listados. O patrimônio líquido investido na classe de segmentos Flls pode incluir, portanto, ambos os tipos de Flls.

(8) Para maiores dados, acessar: https://www.clubefii.com.br.

(9) Empresas listadas na bolsa que atuam no setor imobiliário. Esse grupo abriga grandes empresas, como o grupo Iguatemi, a Multiplan e a Cyrella Properties.

(10) Somente 8 empreendimentos não obtivemos informações quanto à localização.

(11) Essa migração de inquilinos para galpões mais sofisticados é conhecida no mercado financeiro com o termo flight to quality (voo para a qualidade).

(12) A área de atuação das empresas foi selecionada pelos autores a partir da atividade-fim e principal desenvolvida por elas.

(13) Não foi possível obter informação sobre todos os inquilinos e datas de início e fim de contratos. O valor dos contratos também não foi disponibilizado. 


\section{Referências}

AALBERS, M. (2018). Financial geography II: financial geographies of housing and real estate. Progress in Human Geography. Califórnia, v. 43 n. 2, pp. 376-387. https://doi.org/10.1177/0309132518819503.

ANBIMA (2017). Consolidado Estatísticas Flls. Disponível em: < https://www.google.com/url?sa=t\&rct =j\&q=\&esrc=s\&source=web\&cd=\&ved=2ahUKEwiGhsPwn_LxAhWopZUCHez|B20QFjAAegQIBxA D\&url=https\%3A\%2F\%2Fwww.anbima.com.br\%2Fdata\%2Ffiles\%2F02\%2FE1\%2FB8\%2F96\%2FB 9DDA510CD3B4DA568A80AC2\%2FConsolidado-Estatisticas-FII.xls\&usg=AOvVaw2fdrFEDRjTu4L RqzAngubh>. Acesso em: 20 out 2020.

(2020). Ranking de gestores de fundos de investimento (setembro). Disponível em: https:// www.anbima.com.br/pt_br/informar/ranking/fundos-de-investimento/gestores.htm. Acesso em: 28 set 2020 .

AVELINE-DUBACH, N. (2016). Embedment of "Liquid" capital into the built environment: the case of REIT investment in Hong Kong. Issues \& Studies. Londres, v. 52, n. 4, pp. 1-32.

BERTÃO, N. (2020). IPO do fundo imobiliário HSI Logística movimenta $R \$ \$ 1,6$ bilhão. Disponível em: https://valorinveste.globo.com/produtos/fundos-imobiliarios/noticia/2020/12/15/ipo-dofundo-imobiliario-hsi-logistica-movimenta-r-16-bilhao.ghtml. Acesso em: 15 mar 2021.

BOAS, B.; LIMA, L. (2020). Em 4 meses, varejo vai do fundo do poço ao recorde da série histórica. Disponível em: https://valor.globo.com/brasil/noticia/2020/10/09/em-4-meses-varejo-vai-dofundo-do-poco-ao-recorde-da-serie-historica.ghtml. Acesso em: 15 mar 2021.

BYRNE, P.; JACKSON, C.; LEE, S. (2013). Bias or rationality? The case of UK commercial real estate investment. Journal of European Real Estate Research. Bingley, v. 6, n. 1, pp. 6-33. https://doi. org/10.1108/17539261311312960.

CLARK, G.; MONK, A. (2017). Institutional investors in global markets. Oxford, Oxford University Press.

COE, N. M.; DICKEN, P.; HESS, M. (2008). Global production networks: realizing the potential. Journal of Economic Geography. Oxford, v. 8, n. 3, pp. 271-295.

COLLIERS INTERNATIONAL (2020). Market Overview - Relatório de mercado de condomínios logísticos 3T 2020. Disponível em: http://colliers.com.br/3T2020/. Acesso em: 20 jan 2021.

COTIAS, A. (2019). Ativo real compõe carteira de investidor. Valor Econômico. Disponível em: https:// valor.globo.com/financas/noticia/2019/03/13/ativo-real-compoe-carteira-de-investidor.ghtm. Acesso em: 18 mar 2021.

(2020). BlueCap capta $\mathrm{R} \$ 113$ milhões para fundo imobiliário. Valor Econômico. Disponível em: https://valor.globo.com/financas/noticia/2020/05/25/bluecap-capta-r-113-milhoes-parafundo-imobiliario.ghtml. Acesso em: 15 mar 2021.

CUSHMAN e WAKEFIELD (2020). Marketbeat Brasil Industrial T4 2020. Disponível em: <https://www. cushmanwakefield.com/pt-br/brazil/insights/brazil-marketbeats>. Acesso em: 21 jan 2021.

DIB, R. (2021). Mercado logístico: vento em popa. Disponível em: https://www.clubefii.com.br/artigos/ mercado-logistico-vento-em-popa. Acesso em: jul 2021. 
DIXON, A. (2014). The new geography of capitalism. Oxford, Oxford University Press.

DIXON, T.; MARSTON, A. (2002). The effects of online shopping. Journal of Urban Technology. Londres, v. 9, n. 3, pp. 19-47. https://doi.org/10.1080/106307302200004427.

FIX, M. (2007). São Paulo cidade global: fundamentos financeiros de uma miragem. São Paulo, Boitempo.

FRENCH, S.; LEYSHON, A.; WAINWRIGHT, T. (2011). Financializing space, spacing financialization. Progress in Human Geography. Califórnia, v. 35, n. 6, pp. 798-819. https://doi.org/10.1177/0309132510396749

FROUD, J.; JOHAL, S; WILLIAMS, K. (2002). Financialisation and the coupon pool. Capital \& Class. Califórnia, v. 26, n. 3, pp. 119-151. https://doi.org/10.1177/030981680207800106

GOEKING, W. (2021). Magazine Luiza, Via Varejo, Oi? Veja as ações preferidas dos brasileiros em 2020. Disponível em: https://valorinveste.globo.com/mercados/renda-variavel/noticia/2021/01/21/ magazine-luiza-via-varejo-oi-veja-as-acoes-preferidas-dos-brasileiros-em-2020.ghtml. Acesso em: 15 mar 2021.

GORCZYNSKI, T.; KOOIJMAN, D. (2015). The real estate effects of e-commerce for supermarkets in the Netherlands. International Review of Retail, Distribution and Consumer Research. Londres, v. 25, n. 4, pp. 379-406. DOI: https://doi.org/10.1080/09593969.2015.1034750

GUIRONNET, A.; ATTUYER, K.; HALBERT, L. (2016). Building cities on financial assets: the financialisation of property markets and its implications for city governments in the Paris city-region. Urban Studies. Califórnia, v. 53, n. 7, pp. 1442-1464.

HALBERT, L. (2010). L'avantage Métropolitain: la ville en débate. Paris, Presses Universitaires de France. (2013). Les acteurs des marchés financiers font-ils la ville? Vers un agenda de recherche. Disponível em: https://www.espacestemps.net/articles/les-acteurs-des-marches-financiersfont-ils-la-ville/. Acesso em: 15 mar 2021.

HALBERT, L.; ATTUYER, K. (2014). Introduction: The financialisation of urban production: Conditions, mediations and transformations. Urban Studies. Califórnia, v. 53, n. 7, pp. 1347-1361. https://doi. org/10.1177/0042098016635420.

HEBB, T.; SHARMA, R. (2014). New Finance for America's Cities. Regional Studies. Londres, v. 48, n. 3, pp. 485-500.

HENNEBERRY, J.; MOUZAKIS, F. (2014). Familiarity and the determination of yields for regional office property investments in the UK. Regional Studies. Londres, v. 48, n. 3, pp. 530-546. https://doi. org/10.1080/00343404.2013.765556.

HESSE, M. (2004). Land for logistics: locational dynamics, real estate markets and political regulation of regional distribution complexes. Tijdschrift Voor Economische En Sociale Geografie. Nova Jersey, v. 95, n. 2, pp. 162-173. Disponível em: https://orbilu.uni.lu/bitstream/10993/3469/1/ tesg_landforlogistics.pdf. Acesso em: 21 mar 2021. 
INFOMONEY (2020). Amazon anuncia três novos centros de distribuição. Disponível em: https://www. infomoney.com.br/negocios/amazon-anuncia-tres-novos-centros-de-distribuicao/. Acesso em: 15 mar 2021.

(2021). Covid faz do Mercado Livre titã regional e ação salta 185\% em dez meses na Nasdaq. Disponível em: https://www.infomoney.com.br/mercados/covid-faz-do-mercado-livre-titaregional-e-acao-salta-185-em-dez-meses-na-nasdaq/. Acesso em: 15 mar 2021.

INVESTIDOR INSTITUCIONAL (2020a). Rio Bravo aposta em logística impulsionando fundos imobiliários. Disponível em: http://www.investidorinstitucional.com.br/sessoes/mercados/gestores/35384rio-bravo-aposta-na-logistica-impulsionando-fundos-imobiliarios.html. Acesso em: 15 mar 2021.

(2020b). Vinci e Fulwood atuarão juntas em projetos de galpões logísticos. Disponível em: http://www.investidorinstitucional.com.br/sessoes/mercados/gestores/34947-vinci-e-fulwoodatuarao-juntas-em-projetos-de-galpoes-logisticos.html. Acesso em: 15 mar 2021.

KLINK, J.; BARCELLOS DE SOUZA, M. (2017). Financeirização: conceitos, experiências e a relevância para o campo do planejamento urbano brasileiro. Cadernos Metrópole. São Paulo, v. 19, n. 39, pp. 379-406.

LIZIERI, C. (2009). Towers of capital: office markets and international financial services. Wiley-Blackwell, Oxford.

MATTOS, A. (2020). Em 5 meses, varejo prepara mais IPOs que em uma década. Disponível em: https:// valor.globo.com/empresas/noticia/2020/09/08/em-5-meses-varejo-prepara-mais-ipos-que-emuma-decada.ghtml. Acesso em: 15 mar 2021.

ONU NEWS (2020). Banco Mundial prevê pior recessão desde a Segunda Guerra Mundial. Disponível em: https://news.un.org/pt/story/2020/06/1716072. Acesso em: 15 mar 2021.

PEZZOTTI, R. (2020). Amazon é a marca mais valiosa do mundo; Microsoft passa Google em ranking. UOL. Disponível em: https://economia.uol.com.br/noticias/redacao/2020/06/30/amazon-e-amarca-mais-valiosa-do-mundo-microsoft-passa-google-em-lista.htm. Acesso em: jul 2021.

QUINTÃO, C. (2021). Otimista, Prologis eleva aportes em expansão. Disponível em: https://valor. globo.com/empresas/noticia/2021/03/08/otimista-prologis-eleva-aportes-em-expansao.ghtml. Acesso em: 15 mar 2021.

RAIMBAULT, N. (2016). Ancrer le capital dans les flux logistiques : la financiarisation de l'immobilier logistique. Revue d'Économie Régionale \& Urbaine, n. 1, pp. 131-154. https://doi.org/10.3917/ reru.161.0131.

RIZÉRIO, L. (2020). Eventual disputa por correios entre Magalu e Amazon e outras companhias promete ser acirrada, apontam analistas. Disponível em: https://www.infomoney.com.br/mercados/ eventual-disputa-por-correios-entre-magalu-amazon-e-outras-companhias-promete-seracirrada-apontam-analistas/. Acesso em: 15 mar 2021.

SAMOR, G. (2020). Líder em galpões, GLP quer levantar Fll de R\$3 bi. Disponível em: https://braziljournal. com/exclusivo-lider-em-galpoes-glp-quer-levantar-fii-de-r-3-bi?fbclid=IwAR0eTJXDiJYYVR9OQ5C_ pSq3q3WDI7QnS2HNfIO-fQaonxjevDIf5kq-BQU. Acesso em: 15 mar 2021. 
SANFELICI, D. (2018). Investidores financeiros no mercado imobiliário comercial: racionalidades decisórias e repercussões urbanas. In: SERPA, A.; CARLOS, A. F. A. (orgs.). Geografia urbana: desafios teóricos contemporâneos. Salvador, EDUFBA. https://doi.org/10.7476/9788523218812.0013.

SANFELICI, D.; HALBERT, L. (2019). Financial market actors as urban policy-makers: the case of real estate investment trusts in Brazil. Urban Geography. Londres, v. 40, n. 1, pp. 83-103. https://doi. org/10.1080/02723638.2018.1500246.

SANTORO, P.; ROLNIK, R. (2017). Novas frentes de expansão do complexo imobiliário-financeiro em São Paulo. Cadernos Metrópole. São Paulo, v. 19, n. 39, pp. 407-431. http://dx.doi.org/10.1590/22369996.2017-3903.

SIILA (2021a). Via Varejo lança plataforma de logística para sellers. Disponível em: https://www. siilabrasil.blog/post/via-varejo-lança-plataforma-de-log\%C3\%ADstica-para-sellers. Acesso em: 15 mar 2021.

(2021b). Expansão do comércio eletrônico movimenta mercado de galpões. Disponível em: https://www.siilabrasil.blog/post/expansão-do-comércio-eletrônico-movimenta-mercado-degalpões. Acesso em: 15 mar 2021.

SIMÃO, E.; RIBERTIO, M.; OTTA, L. (2020). Eletrobrás, Correios, PPSA e Porto de Santos "são privatizações óbvias", diz Guedes. Disponível em: https://valor.globo.com/brasil/noticia/2020/12/18/ eletrobras-correios-ppsa-e-porto-de-santos-sao-privatizacoes-obvias-diz-guedes.ghtml. Acesso em: 15 mar 2021.

TAUHATA, S. (2019). Fundos imobiliários registram em 2018 o seu melhor ano. Valor Econômico. Disponível em: https://valor.globo.com/financas/noticia/2019/01/20/fundos-imobiliariosregistram-em-2018-o-seu-melhor-ano.ghtml. Acesso em: 18 mar 2021.

(2020). Fundo imobiliário de logística e habitação ganha destaque. Disponível em: https:// valor.globo.com/impresso/noticia/2020/05/25/fundo-imobiliario-de-logistica-e-habitacaoganha-destaque.ghtml. Acesso em: 15 mar 2021.

THE ECONOMIST (2018). The global logistics business is going to be transformed by digitisation. Disponível em: https://www.economist.com/briefing/2018/04/26/the-global-logistics-businessis-going-to-be-transformed-by-digitisation. Acesso em: 15 mar 2021.

THEURILLAT, T.; CREVOISIER, O. (2013). Sustainability and the anchoring of capital: negotiations surrounding two major urban projects in switzerland. Regional Studies. Londres, v. 48, n. 3, pp. 501-515. https://doi.org/10.1080/00343404.2013.787160.

THEURILLAT, T.; RÉRAT, P.; CREVOISIER, O. (2015). The real estate markets: players, institutions and territories. Urban Studies. Califórnia, v. 52, n. 8, pp. 1414-1433.

UQBAR (2020). Anuário Uqbar 2020 - Fundos de Investimento Imobiliário, 13a Edição. Disponível em: https://www.uqbar.com.br/anuario-fundo-de-investimento-imobiliario-2020/. Acesso em: 1은 fev 2021.

(2021). Anuário Uqbar 2021 - Fundos de Investimento Imobiliário. Disponível em: https://www. uqbar.com.br/anuarios2021/fii.php. Acesso em: maio 2021. 
WIJBURG, G.; AALBERS, M. B. (2017). The internationalization of commercial real estate markets in France and Germany. Competition and Change. Califórnia, v. 21, n. 4, pp. 301-320. https://doi. org/10.1177/1024529417712040.

WORZALA, E. M.; MCCARTHY, A. M.; DIXON, T.; MARSTON, A. (2002). E-commerce and retail property in the UK and USA. Journal of Property Investment \& Finance. Nova York, v. 20, n. 2, pp. 142-158. https://doi.org/10.1108/14635780210420034.

ZONTA D’AVILLA, M. (2020). Fundos imobiliários de logística são os vencedores da pandemia e devem sair fortalecidos da crise, dizem gestores. Disponível em: https://www.infomoney.com.br/ onde-investir/fundos-imobiliarios-de-logistica-sao-os-vencedores-da-pandemia-e-devem-sairfortalecidos-da-crise-dizem-gestores/. Acesso em: 15 mar 2021.

Texto recebido em 19/mar/2021

Texto aprovado em 14/jul/2021 